\title{
Review
}

\section{Multimodal Role of PACAP in Glioblastoma}

\author{
Agata Grazia D'Amico ${ }^{1,+}$, Grazia Maugeri ${ }^{2,+}{ }^{\oplus}$, Luca Vanella ${ }^{1}\left(\mathbb{D}\right.$, Valeria Pittalà ${ }^{1}\left(\mathbb{D}\right.$, Dora Reglodi $^{3}$ \\ and Velia $D^{\prime}$ Agata ${ }^{2, *(D)}$
}

1 Department of Drug and Health Sciences, University of Catania, 95125 Catania, Italy; agata.damico@unict.it (A.G.D.); lvanella@unict.it (L.V.); valeria.pittala@unict.it (V.P.)

2 Section of Anatomy, Histology and Movement Sciences, Department of Biomedical and Biotechnological Sciences, University of Catania, 95100 Catania, Italy; graziamaugeri@unict.it

3 MTA-PTE PACAP Research Group, Department of Anatomy, University of Pécs Medical School, 7624 Pécs, Hungary; dora.reglodi@aok.pte.hu

* Correspondence: vdagata@unict.it

+ These authors contributed equally.

Citation: D'Amico, A.G.; Maugeri,

G.; Vanella, L.; Pittalà, V.; Reglodi, D.; D'Agata, V. Multimodal Role of PACAP in Glioblastoma. Brain Sci. 2021, 11, 994. https://doi.org/ 10.3390/brainsci11080994

Academic Editor: David Brown

Received: 23 June 2021

Accepted: 24 July 2021

Published: 28 July 2021

Publisher's Note: MDPI stays neutral with regard to jurisdictional claims in published maps and institutional affiliations.

Copyright: (C) 2021 by the authors. Licensee MDPI, Basel, Switzerland. This article is an open access article distributed under the terms and conditions of the Creative Commons Attribution (CC BY) license (https:// creativecommons.org/licenses/by/ $4.0 /)$.

\begin{abstract}
Glioblastoma multiforme (GBM) is the deadliest form of brain tumors. To date, the GBM therapeutical approach consists of surgery, radiation-therapy and chemotherapy combined with molecules improving cancer responsiveness to treatments. In this review, we will present a brief overview of the GBM classification and pathogenesis, as well as the therapeutic approach currently used. Then, we will focus on the modulatory role exerted by pituitary adenylate cyclase-activating peptide, known as PACAP, on GBM malignancy. Specifically, we will describe PACAP ability to interfere with GBM cell proliferation, as well as the tumoral microenvironment. Considering its anti-oncogenic role in GBM, synthesis of PACAP agonist molecules may open new perspectives for combined therapy to existing gold standard treatment.
\end{abstract}

Keywords: glioblastoma multiforme; tumoral microenvironment; hypoxia; PACAP

\section{Introduction}

Gliomas represent the most frequent malignant tumor affecting the central nervous system (CNS), including all glial cell-derived cancers. Based on World Health Organization classification, four types of gliomas can be classified: astrocytoma of grade I and grade I, representing astrocytic tumor, the grade III astrocytoma, consisting in anaplastic tumor, and grade IV astrocytoma or glioblastoma multiforme (GBM) [1]. The latter represents the deadliest brain cancer, with high cell heterogeneity and poor prognosis since it is characterized by therapeutic resistance and relapse after surgery. To counteract this issue, many studies have focused on identification of a new therapeutic approach consisting in co-administration of new molecules to the existing gold-standard treatment. In this way, the researchers have attempted to increase the therapy effectiveness, rendering tumoral tissue more vulnerable and counteracting its chemoresistance. Among new propositions, the inhibition of malignant cells infiltration into the surrounding parenchyma seems to be the more promising strategy.

Pituitary adenylate cyclase-activating polypeptide (PACAP) is a pleiotropic peptide first isolated from ovine hypothalamus by Miyata and co-workers in 1989 [2]. This peptide is widely expressed in the CNS where it exerts different effects depending on the pathophysiological condition of tissue or organ [3-7]. Recent findings have demonstrated its involvement in various tumors, including GBM, where it exerts different effects depending on histopathological features of cancer [8-13]. In this review, we will first provide an overview of the GBM classification and existing therapy, highlighting the recent insight about the combined therapeutics approach reported in the literature. Finally, we will report existing findings related to PACAP involvement in GBM malignancy and the molecular mechanisms underlying its anti-oncogenic activity. 


\section{Glioblastoma Multiforme: Classification, Pathogenesis and Therapeutic Approaches}

GBM is a lethal form of brain cancer affecting adults with poor prognosis, since the median survival of patients is between 14-17 months [14]. Based on different histologic features, the World Health Organization (WHO) classifies gliomas into astrocytoma of grades I, II, III or IV, the latter also being known as GBM [1,15]. By using genomic and transcriptomic analyses, GBM is also classified into four molecular subtypes [16,17]. Accordingly, a recent review has listed some criteria to subtype GBM, emphasizing their clinical relevance to develop a specific targeted therapy [18]. Based on expression of specific markers, it is possible to distinguish a Proneural, Neural, Mesenchymal or Classical GBM subtype [17]. In 2017, Wang et al. proposed a new classification including Classical, Proneural, and Mesenschymal GBM, since Neural subtype consist of non-tumor cells [19]. In accordance with this evidence, Teo et al. validated three robust GBM-subtypes: Proneural/Neural, Classical, and Mesenchymal by using a gene-classifier on six different platforms among various group population [20]. Moreover, large scale genomic studies extrapolated from The Cancer Genome Atlas (TCGA) have revealed various mutations on oncogene and/or onco-suppressor genes by subtyping GBM, including TP53, PTEN, Neurofibromin-1 and epidermal growth factor receptor (EGFR). In particular, the amplification of EGFR is detected in approximately $50 \%$ of primary tumors and occurs in the initial or recurrent stage. A specific EGFR mutation, known as EGFR variant III mutation, was detected in glioblastoma tissue in the initial phase as well as in relapse, although in the latter frequency was lower than in tumor tissue from the initial surgery [21,22]. Controversial findings concerning the correlation between tumor progression and EGFR amplification or EGFRvIII mutation are reported. Accordingly, some studies associated their alteration with an enhanced survival rate while others with bad prognosis [23-25]. Based on isocitrate dehydrogenase (IDH) enzyme mutations, it is possible to predict GBM outcome. In fact, characterization of IDH1 and IDH2 isoforms have assumed a prognostic value. In particular, patients carrying on mutations of these variants have a better response to standard treatment, as well as longer survival when compared to wild-type IDH1 patients [26-28]. An additional classification is based on identification of MGMT promoter methylation, involving $45 \%$ of GBM patients.

More recently, by following new recommendations proposed by cIMPACT-NOW research group, the upcoming WHO classification 2021 on CNS tumors discriminates between adult and pediatric GBM $[29,30]$.

GBM is characterized by a heterogeneous mass, made up of infiltrating cells, stroma, blood vessels, secreted molecules and surrounding matrix. All these factors affect cancer development by promoting invasion and recurrence. In fact, cancer microenvironment contributes to tumor tissue transcriptional and genetic profile by comprising genes characterizing the different GBM molecular subtypes. A better understanding of tumor intrinsic signals, microenvironment and their interplay could help to understand the pathogenetic mechanism involved in malignancy and find a new combination for chemo- and immunotherapy strategies to address a more specific individual therapy.

It has been largely demonstrated that microenvironment hypoxia represents a feature common to various solid tumors, including GBM, and it is linked to poor prognosis as well as therapy resistance [31-33]. In 1953, Gray and co-workers first demonstrated that hypoxic microenvironment determines tumor radio-resistance in different animal models [34]. Subsequently, other investigators have detailed this correlation [35,36]. More specifically, hypoxia contributes to the creation of an environmental cue directly responsible for cancer stem cells (CSCs) maintenance [37-40]. The latter escape radiotherapy or chemotherapy are directly responsible for cell genesis, aggressiveness, self-renewal and multipotency leading to cancer recurrence [41,42]. Furthermore, hypoxia reduces the expression of genes responsible for DNA repair, by inducing its mutations [43]; it also drives the transcription of hypoxia-inducible factors (HIFs), including HIF- $1 \alpha$ and HIF- $2 \alpha$ in GSCs. High HIF- $1 \alpha$ levels were detected either in GBM GSCs or non-GSCs, whereas HIF- $2 \alpha$ enhanced expression were reported exclusively in GSCs [44]. 
Hypoxia signaling cascade activates many downstream target genes responsible for enhancing cell invasiveness and uncontrolled neovascularization, including vascular endothelial growth factor (VEGF) [45]. Furthermore, it has been demonstrated that GSC population determines a perivascular induction of VEGF, which in turn leads to new vessel formation [46]. On the other hand, VEGF through an autocrine mechanism binds VEGFR2 receptor present on the GSCs surface, promoting the maintenance of the stemlike phenotype [35,47]. Another mechanism responsible for new vessel formation is the hypoxia-driven vasculogenesis. In this case, HIF-1 $\alpha$ induces GSCs to secrete stromal cellderived factor 1 (SDF-1), determining an increased attraction of heterogeneous population of bone marrow-derived endothelial progenitor cells, including endothelial progenitor cells (EPC), in tumoral periphery through mediation of CXC chemokine receptor type 4 (CXCR-4). The EPCs are involved in proliferation, as well as in trophic support for endothelial cells $[48,49]$.

The effect of the tumoral hypoxic microenvironment is not limited to angiogenesis since it also regulates the transition of tumor epithelial cells towards the more malignant mesenchymal phenotype. The epithelial mesenchymal transition (EMT) is a key process involved in tumoral metastasis. Recent papers have demonstrated that the hypoxic microenvironment within tumor mass recruits circulating or residential myeloid cells (i.e., macrophages or microglia) into stroma, as well as triggers the activation of the EMT process [50-52].

Overall, the key role performed by the hypoxic microenvironment to drive progression of tumor towards malignancy by promoting different biological events is evident. Therefore, the use of drugs targeting tumor hypoxic pathways could improve radiation response in GBM patients [53].

Considering the structural heterogeneity of tumor mass, the actual approach consists of a multimodal treatment combining surgery, radiation and chemotherapy with additional molecules [15], also finalized to counteract recurrence.

Temozolomide (TMZ) is a molecule used in gold-standard treatment of GBM. This molecule is a DNA alkylating agent capable of inducing destruction of cancer cells since it prevents DNA replication. Usually, this drug is co-administered with radiotherapy for a further six cycles for maintenance $[54,55]$. Hepatic impairment and myelosuppression represent the most frequent side-effects [56].

Since VEGF overexpression is commonly found in GBM [57,58], targeting this factor is considered a promising therapeutic approach to counteract tumor progression $[59,60]$. Among the antiangiogenic proposed therapy, Bevacizumab (BV) has been approved by the US Food and Drug Administration (FDA) to treat GBM in adult [61]. It is a monoclonal antibody recognizing vascular endothelial growth factor (VEGF) and then capable of counteracting uncontrolled neovascularization. However, response to BV treatment seems to depend on the GBM molecular subtype [62]. A previous study demonstrated that BV was efficacious in patients with IDH1 wild type proneural glioblastoma [63], whereas it failed in some other treated patients [64]. Moreover, it has been reported that BV showed limited benefit on recurrent GBM, whereas it has no effects on the survival of patients with primary GBM $[65,66]$. This effect could be related to cells' epithelial-mesenchymal transition (EMT), responsible of drug-resistance and tumor relapse [67,68]. Accordingly, Huang et al., 2017 [69], demonstrated in an in vitro study that BV is capable of increasing cell migration and EMT markers expression.

Recently, the effect of natural compounds, including cannabinoid [70] and an active natural bioflavonoid, Chrysin, have also been tested in GBM. The latter has been shown to exert an antiproliferative effect on glioblastoma cells [71]. Many other molecules have shown promising therapeutic effects, such as the inhibitor of epidermal growth factor receptor (EGFR), known as erlotinib. Unfortunately, many of these drugs do not cross the blood-brain barrier and, consequently, did not show any efficacy on patients' survival during phase II of the clinical trial [72,73]. 
More recently, in an open-label phase 2 trial, known as REGOMA, researchers tested regorafenib, an oral multikinase inhibitor of angiogenic and oncogenic receptor tyrosine kinases, to treat recurrent glioblastoma [74-77]. It is noteworthy that Detti et al. reported an excellent response in a patient after three months of treatment with regorafenib [78].

\section{PACAP and Its Related Receptors in Cancer}

Pituitary adenylate cyclase-activating polypeptide (PACAP) is a peptide that belongs to the secretin/glucagon/growth hormone-releasing hormone/vasoactive intestinal peptide (VIP) family members, widely expressed in the CNS and in peripheral organs where it exerts different roles in a tissue-specific manner [79-84]. This peptide was isolated in 1989 from ovine hypothalamus [2]. It exists in two isoforms derived from the same precursor: PACAP-38, constituted of 38 amino acids, and PACAP-27 truncated in C-terminal domain, including 27 amino acids $[85,86]$. PACAP- 38 represents the predominant form in mammalian tissues. The various effects of PACAP are mediated by binding three different G-protein coupled receptors: PAC1 and VPAC receptors (VPAC1 and VPAC2). PAC1 shows higher affinity with PACAP rather than VIP, whereas both peptides show the same affinity to bind VPAC1 and VPAC2 receptors $[87,88]$. Different PAC1 receptor splice variants exist: Null, Hip, Hop1, Hop2, Hiphop1, Hiphop2, short and very short isoforms [89]. To date, several papers have summarized the distribution of PACAP and its receptors in different organs, including stomach, kidney, articular cartilage, human corneal endothelium, as well as in the CNS [90-94].

By binding to its receptors, PACAP can trigger different signaling pathways downstream adenylate-cyclase (AC) or phospholipase-C (PLC) activation, as well as calciumregulated mechanisms [95]. In particular, PAC1 receptor is coupled either to G-protein alpha subunits $\mathrm{Gs}$ and $\mathrm{Gq}$ transmembrane receptors that mediate adenylyl cyclase/cAMP and phospholipase C (PLC)/DAG/IP3 signaling cascades, respectively [88,96]. More specifically, the PAC1 isoforms Null, Hop1, and Hop2 induce both pathways AC and PLC, whereas Hip isoform induces exclusively AC activation. The variants Hiphop1 and Hiphop2 represent an intermediate phenotype [97-99]. On the other hand, the VPAC subtypes are coupled predominantly to the $\mathrm{G} \alpha$ s transmembrane receptor that modulates cAMP signaling cascade $[100,101]$.

Many studies have pointed out the role exerted by PACAP in some physiological conditions such as ageing, as well as in different pathologies, including neurodegenerative diseases, such as ischemia, traumatic brain injury, amyotrophic lateral sclerosis and retinopathy [102-115]. During the last decade, a lot of investigations have also reported the involvement of PACAP in different tumors, such as testicular, lung, breast, prostate, colon and pancreatic cancer, as well as neuroblastoma and glioblastoma [8,10,116-118]. However, its controversial role has been emphasized since it triggers different effects depending on the histopathological hallmarks of the tumor, the stage of disease as well as peptide concentration and time of treatment $[119,120]$. It is noteworthy that it has also been demonstrated that PACAP is capable of interfering with cancer progression even though it shows contrasting effects $[87,121]$. In fact, it promoted cell proliferation in some cases, whereas, in others, it reduced cell growth by inducing apoptotic cell death. Its endogenous expression, as well as the levels of its receptors seems to be dysregulated in the different neoplasms. More specifically, overexpression of PAC1 and VPAC1 receptors was detected in lung cancer, breast cancer, colon cancer, prostate adenocarcinoma, and pancreas tumor, whereas VPAC 2 receptor upregulation was detected in lung adenocarcinomas and neuroendocrine cancers [122-124]. However, reduced expression of both PACAP and its specific PAC1 receptor was described in pancreas adenocarcinoma samples [118] and reduced expression was measured with radioimmunoassay in lung, kidney and colon cancer samples in contrast to elevated levels in prostate cancer $[125,126]$. An altered staining pattern could be observed in other types of cancer, such as thyroid carcinoma and testicular cancer $[117,127]$. 


\section{PACAP Involvement in GBM Malignancy}

The presence of PACAP and related receptors was shown in human gliomas [128-132]. Recently, we have analyzed the peptide expression in human GBM samples by detecting lower endogenous PACAP concentration as compared to its receptors level [9].

The functional role of PACAP has been investigated by using several in vitro models of glioblastoma cells. In particular, an immunohistochemical study demonstrated that VPAC1 and VPAC2 are expressed in normal brain and glioma tissues by revealing a high cytoplasmatic expression related to grade of malignancy. The authors have also reported the differential nuclear localization of VPAC1, which increased with glioma grades, in contrast to weak nuclear staining of VPAC2 [133]. In 1996, Vertongen et al. [134] reported that PACAP significantly decreased proliferation of T98G human glioma cells; conversely, Sokolowska and Nowak (2008) [135] demonstrated that this peptide enhanced mouse C6 glioma cell proliferation after its exogenous administration. Considering these contrasting results, it has been hypothesized that the effect of the peptide depends on the origin species of studied cell lines. It has also been reported that PACAP treatment enhanced C6 glioma cell proliferation already at low concentration, ranging between $10^{-15}$ to $10^{-13} \mathrm{M}$ [136]. Accordingly, our research group showed that PACAP increased C6 glioma cell viability already at $100 \mathrm{nM}$ concentration after $48 \mathrm{~h}$ treatment [13]. By using two human glioblastoma cell lines isolated from different parts of a single tumor (known as M059K and M59j cells), it has also been proved that PACAP agonists reduced cancer cell migration, even though they did not affect their proliferation. Furthermore, these authors have shown that PACAP regulated cell invasion by acting through AKT signaling pathway [137,138]. Considering the highly invasive nature of GBM, these findings demonstrated that the potential antioncogenic property of this peptide is mediated through PAC1/VIPAC receptors activation. A recent study further characterized the molecular mechanism underling PACAP antiinvasive effect on GBM cells demonstrating that it acts by blocking PI3K/Akt and sonic hedgehog-GLI1 (Shh/GLI1) pathways [139]. The latter are the main signaling cascades responsible of GBM progression [140]. Furthermore, PI3K/Akt overactivation induced upregulation of MMP-2 and MMP-9, which in turn conferred to tumor cells the proteolytic capability to infiltrate normal tissue [141].

As mentioned above, the tumoral microenvironment plays a key role in cancer malignancy. It has been demonstrated that calorie restriction (CR) is efficacious in preventing cancer progression by increasing lifespan. In fact, it has been demonstrated that CR reduced cell proliferation by interfering with microenvironmental levels of several anabolic hormones, growth factors, inflammatory cytokines and oxidative stress agents [142]. We have investigated the effect of PACAP in C6 glioma cells cultured in serum free media, mimicking the microenvironmental tumoral condition under CR. Results have demonstrated that peptide treatment exacerbated CR-derived effects by leading to reduction of cell proliferation, as well as expression of nestin, a marker of cellular malignancy. This evidence allowed us to hypothesize that the effect of PACAP also depends on microenvironmental conditions [13].

High cell proliferation produces in tumor mass hypoxic areas responsible for its malignant progression [143]. In these regions, we have demonstrated that PACAP acts by modulating the hypoxic pathway. Specifically, peptide treatment significantly reduced HIF- $1 \alpha$ and HIF- $2 \alpha$ levels in glioblastoma cells by inducing a drastic inhibition of PI3K/Akt and ERK1/2 signaling cascades, involved in uncontrolled cell proliferation. The hypoxic microenvironment also promotes the oncogenic program by inducing EGFR transactivation. This receptor is recognized as a prognostic marker of an advanced tumor stage since its anomalous expression is usually linked to reduced patient survival $[144,145]$. In our investigations, we found that PACAP also abrogated the aberrant EGFR transactivation occurring in GBM cells cultured in hypoxia, probably through inhibition of PI3K/Akt and MAPK/ERK pathway (Figure 1). 


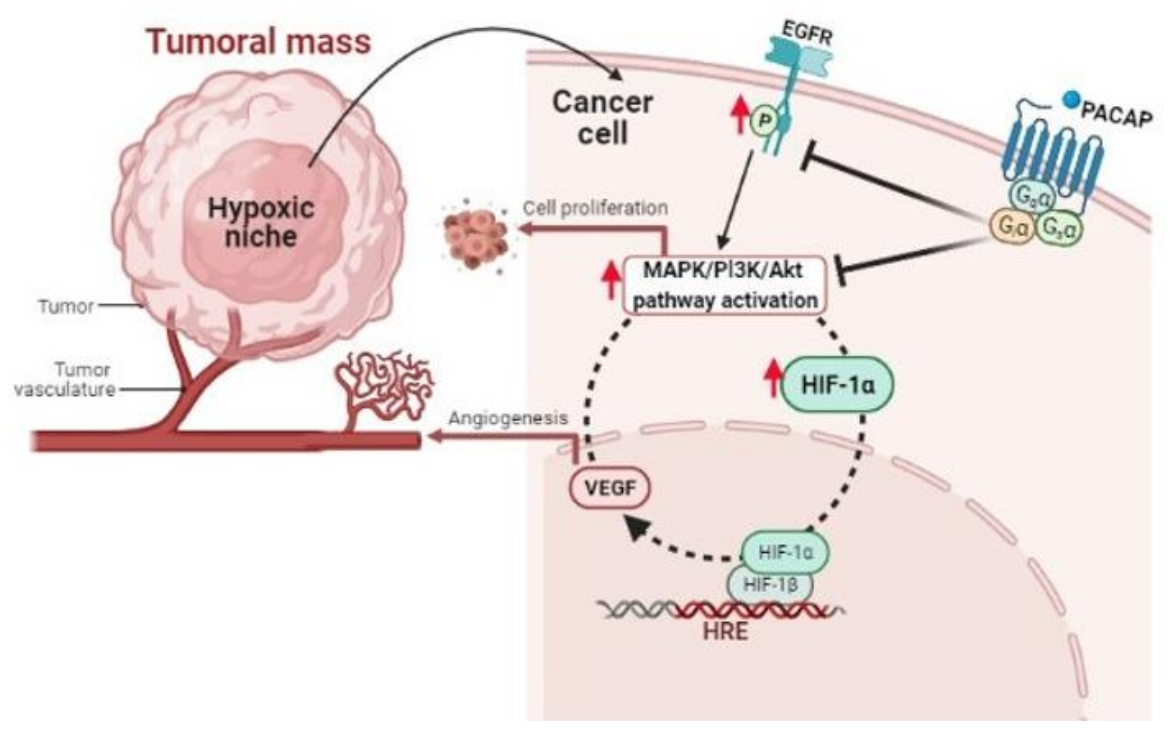

Figure 1. Schematic representation showing the PACAP modulatory effect in cellular microenvironment of hypoxic niches.

Recently, it has also been demonstrated that PACAP causes EGFR transactivation in non-small cell lung cancer in an oxygen-dependent manner that involves phospholipase $\mathrm{C}$ but not protein kinase A. Therefore, it could be hypothesized that the peptide' effect in GBM may be mediated through a similar mechanism [146-148].

By using confocal laser scanning microscopy, we recently investigated the expression of PACAP and its high affinity related receptor, PAC1R, in hypoxic areas visualized on human GBM sections. PACAP co-localized only with HIF- $1 \alpha$, while PAC1R was present in hypoxic regions, as well as in tumoral stroma. Furthermore, PACAP or PAC1R co-localized with HIF $1 \alpha$ in the cytoplasm or in the nucleus of tumor cells. This evidence confirmed a strict correlation between peptides and the hypoxic area in GBM. In this study, we have also demonstrated that PACAP interfered with uncontrolled neovascularization occurring in hypoxic niche. By using U87MG cells exposed to hypoxia, we observed that the peptide decreased VEGF intracellular expression, as well as its release in the growth medium. Culturing H5V endothelial cells in conditioned medium derived from GBM cells treated with PACAP under hypoxic condition, we observed a significant reduction in the number of tube-like structures, representing a model in vitro of micro-vessels formation. It is noteworthy that we have provided the first evidence demonstrating that the peptide interferes with the hypoxia-induced EMT process. As revealed by immunolocalization analyses, PACAP and PAC1R are expressed either in mesenchymal or in epithelial cells of GBM samples. Precisely, PACAP and its receptor co-localized in areas of human GBM expressing vimentin and MMP-2, two markers of mesenchymal phenotype, as well as in cells expressing ZO-1, a marker of epithelial phenotype. Moreover, in U87MG cells exposed to hypoxia, PACAP significantly reduced the mesenchymal phenotype markers, vimentin and matrix metalloproteinases MMP-2 and MMP-9, and, on the other hand, it increased ZO-1 expression [149]. This demonstrated that the exogenous administration of PACAP interfered with the EMT process by counteracting the epithelial cell differentiation towards mesenchymal phenotype. It has been recently reported that increased protein levels of MMP-2 and MMP-9 are responsible of extracellular matrix and basement membrane degradation allowing cancer cells to spread toward surrounding tissue [150]. In this regard, we have demonstrated that PACAP was able to counteract migration of U87MG cells exposed to hypoxia by interfering with the EMT event. In fact, it significantly reduced the number of Vimentin and CD44 immuno-positive migrating cells in the wounded area by using a model in vitro invasion assay. In accord, CD44 immunoreactivity is detected in about $55.55 \%$ of GBM, where its increased levels are related to shorter patients' survival [151-153]. 


\section{Conclusions}

To date, data reported in the literature suggest that PACAP acts on GBM malignancy by interfering with cell proliferation as well as the tumoral microenvironment. In this study, we have highlighted its effect on modulation of HIFs pathway triggered in the hypoxic niches of tumor mass. The current therapeutical approach for GBM has many limits in terms of survival benefit. Therefore, the identification of new molecules capable of increasing glioma cell sensitivity to therapy might be desirable. Considering that PACAP does not cross the blood brain barrier, it could be helpful to synthetize new molecules targeting a peptide-driven signaling system to use in combination treatment with the existing therapeutic approach.

Author Contributions: Conceptualization, A.G.D., G.M., V.D.; writing—original draft preparation, A.G.D., G.M.; writing - review and editing, V.D., L.V. and D.R.; visualization, V.P. and L.V.; supervision, V.D., V.P. and D.R.; funding acquisition, A.G.D. All authors have read and agreed to the published version of the manuscript.

Funding: This research was funded by the STARTING GRANT 2020, title "Regulatory effect of PACAP-ADNP axis and its involvement in modulation of Glioblastoma multiforme", Department of Drug Science, University of Catania. MTA-TKI14016; NKFIH K135457, NAP2017-1.2.1-NKP-201700002; FIKPIII, EFOP-3.6.2-00008, "The role of neuro-inflammation in neurodegeneration: from molecules to clinics", GINOP-2.3.2-15-2016-00050 "PEPSYS".

Conflicts of Interest: The authors declare no conflict of interest.

\section{References}

1. Friedmann-Morvinski, D. Glioblastoma heterogeneity and cancer cell plasticity. Crit. Rev. Oncog. 2014, 19, 327-336. [CrossRef] [PubMed]

2. Miyata, A.; Arimura, A.; Dahl, R.R.; Minamino, N.; Uehara, A.; Jiang, L.; Culler, M.D.; Coy, D.H. Isolation of a novel 38 residue-hypothalamic polypeptide which stimulates adenylate cyclase in pituitary cells. Biochem. Biophys. Res. Commun. 1989, 164, 567-574. [CrossRef]

3. Cavallaro, S.; D'Agata, V.; Guardabasso, V.; Travali, S.; Stivala, F.; Canonico, P.L. Differentiation induces pituitary adenylate cyclase-activating polypeptide receptor expression in PC-12 cells. Mol. Pharmacol. 1995, 48, 56-62.

4. D'Agata, V.; Cavallaro, S.; Stivala, F.; Canonico, P.L. Tissue-specific and developmental expression of pituitary adenylate cyclase-activating polypeptide (PACAP) receptors in rat brain. Eur. J. Neurosci. 1996, 8, 310-318. [CrossRef] [PubMed]

5. Canonico, P.L.; Copani, A.; D'Agata, V.; Musco, S.; Petralia, S.; Travali, S.; Stivala, F.; Cavallaro, S. Activation of pituitary adenylate cyclase-activating polypeptide receptors prevents apoptotic cell death in cultured cerebellar granule cells. Ann. N. Y. Acad. Sci. 1996, 805, 470-472. [CrossRef]

6. Waschek, J.A. VIP and PACAP: Neuropeptide modulators of CNS inflammation, injury, and repair. Br. J. Pharmacol. 2013, 169, 512-523. [CrossRef]

7. Toth, D.; Szabo, E.; Tamas, A.; Juhasz, T.; Horvath, G.; Fabian, E.; Opper, B.; Szabo, D.; Maugeri, G.; D’Amico, A.G.; et al. Protective Effects of PACAP in Peripheral Organs. Front. Endocrinol. 2020, 11, 377. [CrossRef] [PubMed]

8. Moody, T.W.; Nuche-Berenguer, B.; Jensen, R.T. Vasoactive intestinal peptide/pituitary adenylate cyclase activating polypeptide, and their receptors and cancer. Curr. Opin. Endocrinol. Diabetes Obes. 2016, 23, 38-47. [CrossRef]

9. Maugeri, G.; D'Amico, A.G.; Reitano, R.; Magro, G.; Cavallaro, S.; Salomone, S.; D'Agata, V. PACAP and VIP Inhibit the Invasiveness of Glioblastoma Cells Exposed to Hypoxia through the Regulation of HIFs and EGFR Expression. Front. Pharmacol. 2016, 7, 139. [CrossRef]

10. Maugeri, G.; D'Amico, A.G.; Rasà, D.M.; Saccone, S.; Federico, C.; Cavallaro, S.; D'Agata, V. PACAP and VIP regulate hypoxiainducible factors in neuroblastoma cells exposed to hypoxia. Neuropeptides 2018, 69, 84-91. [CrossRef]

11. Castorina, A.; Giunta, S.; Scuderi, S.; D'Agata, V. Involvement of PACAP/ADNP signaling in the resistance to cell death in malignant peripheral nerve sheath tumor (MPNST) cells. J. Mol. Neurosci. 2012, 48, 674-683. [CrossRef] [PubMed]

12. Castorina, A.; Scuderi, S.; D'Amico, A.G.; Drago, F.; D'Agata, V. PACAP and VIP increase the expression of myelin-related proteins in rat schwannoma cells: Involvement of PAC1/VPAC2 receptor-mediated activation of PI3K/Akt signaling pathways. Exp. Cell Res. 2014, 322, 108-121. [CrossRef] [PubMed]

13. D'Amico, A.G.; Scuderi, S.; Saccone, S.; Castorina, A.; Drago, F.; D'Agata, V. Antiproliferative effects of PACAP and VIP in serum-starved glioma cells. J. Mol. Neurosci. 2013, 51, 503-513. [CrossRef] [PubMed]

14. Lefranc, F.; Le Rhun, E.; Kiss, R.; Weller, M. Glioblastoma quo vadis: Will migration and invasiveness reemerge as therapeutic targets? Cancer Treat. Rev. 2018, 68, 145-154. [CrossRef]

15. Anjum, K.; Shagufta, B.I.; Abbas, S.Q.; Patel, S.; Khan, I.; Shah, S.A.A.; Akhter, N.; Hassan, S.S.U. Current status and future therapeutic perspectives of glioblastoma multiforme (GBM) therapy: A review. Biomed. Pharmacother. 2017, 92, 681-689. [CrossRef] 
16. Phillips, H.S.; Kharbanda, S.; Chen, R.; Forrest, W.F.; Soriano, R.H.; Wu, T.D.; Misra, A.; Nigro, J.M.; Colman, H.; Soroceanu, L.; et al. Molecular subclasses of high-grade glioma predict prognosis, delineate a pattern of disease progression, and resemble stages in neurogenesis. Cancer Cell 2006, 9, 157-173. [CrossRef]

17. Verhaak, R.G.; Hoadley, K.A.; Purdom, E.; Wang, V.; Qi, Y.; Wilkerson, M.D.; Miller, C.R.; Ding, L.; Golub, T.; Mesirov, J.P.; et al. Integrated genomic analysis identifies clinically relevant subtypes of glioblastoma characterized by abnormalities in PDGFRA, IDH1, EGFR, and NF1. Cancer Cell 2010, 17, 98-110. [CrossRef] [PubMed]

18. Lee, E.; Yong, R.L.; Paddison, P.; Zhu, J. Comparison of glioblastoma (GBM) molecular classification methods. Semin. Cancer Biol. 2018, 53, 201-211. [CrossRef] [PubMed]

19. Wang, Q.; Hu, B.; Hu, X.; Kim, H.; Squatrito, M.; Scarpace, L.; de Carvalho, A.C.; Lyu, S.; Li, P.; Li, Y.; et al. Tumor Evolution of Glioma-Intrinsic Gene Expression Subtypes Associates with Immunological Changes in the Microenvironment. Cancer Cell 2017, 32, 42-56.e6. [CrossRef]

20. Teo, W.Y.; Sekar, K.; Seshachalam, P.; Shen, J.; Chow, W.Y.; Lau, C.C.; Yang, H.; Park, J.; Kang, S.G.; Li, X.; et al. Relevance of a TCGA-derived Glioblastoma Subtype Gene-Classifier among Patient Populations. Sci. Rep. 2019, 9, 7442. [CrossRef]

21. Brennan, C.W.; Verhaak, R.G.; McKenna, A.; Campos, B.; Noushmehr, H.; Salama, S.R.; Zheng, S.; Chakravarty, D.; Sanborn, J.Z.; Berman, S.H.; et al. The somatic genomic landscape of glioblastoma. Cell 2013, 155, 462-477. [CrossRef]

22. Felsberg, J.; Hentschel, B.; Kaulich, K.; Gramatzki, D.; Zacher, A.; Malzkorn, B.; Kamp, M.; Sabel, M.; Simon, M.; Westphal, M.; et al. Epidermal Growth Factor Receptor Variant III (EGFRvIII) Positivity in EGFR-Amplified Glioblastomas: Prognostic Role and Comparison between Primary and Recurrent Tumors. Clin. Cancer Res. Off. J. Am. Assoc. Cancer Res. 2017, 23, 6846-6855. [CrossRef] [PubMed]

23. Shinojima, N.; Tada, K.; Shiraishi, S.; Kamiryo, T.; Kochi, M.; Nakamura, H.; Makino, K.; Saya, H.; Hirano, H.; Kuratsu, J.; et al. Prognostic value of epidermal growth factor receptor in patients with glioblastoma multiforme. Cancer Res. 2003, 63, 6962-6970. [PubMed]

24. Montano, N.; Cenci, T.; Martini, M.; D’Alessandris, Q.G.; Pelacchi, F.; Ricci-Vitiani, L.; Maira, G.; De Maria, R.; Larocca, L.M.; Pallini, R. Expression of EGFRvIII in glioblastoma: Prognostic significance revisited. Neoplasia 2011, 13, 1113-1121. [CrossRef] [PubMed]

25. Bieńkowski, M.; Piaskowski, S.; Stoczyńska-Fidelus, E.; Szybka, M.; Banaszczyk, M.; Witusik-Perkowska, M.; Jesień-Lewandowicz, E.; Jaskólski, D.J.; Radomiak-Załuska, A.; Jesionek-Kupnicka, D.; et al. Screening for EGFR amplifications with a novel method and their significance for the outcome of glioblastoma patients. PLoS ONE 2013, 8, e65444. [CrossRef]

26. Yan, H.; Parsons, D.W.; Jin, G.; McLendon, R.; Rasheed, B.A.; Yuan, W.; Kos, I.; Batinic-Haberle, I.; Jones, S.; Riggins, G.J.; et al. IDH1 and IDH2 mutations in gliomas. N. Engl. J. Med. 2009, 360, 765-773. [CrossRef]

27. Qi, S.; Lei, Y.; Si, G.; Ding, Y.; Han, H.; Zhang, X.; Wu, L.; Fei, Y. IDH mutations predict longer survival and response to temozolomide in secondary glioblastoma. Cancer Sci. 2012, 103, 269-273.

28. Beiko, J.; Suki, D.; Hess, K.R.; Fox, B.D.; Cheung, V.; Cabral, M.; Shonka, N.; Gilbert, M.R.; Sawaya, R.; Prabhu, S.S.; et al. IDH1 mutant malignant astrocytomas are more amenable to surgical resection and have a survival benefit associated with maximal surgical resection. Neuro-Oncol. 2014, 16, 81-91. [CrossRef]

29. Louis, D.N.; Wesseling, P.; Aldape, K.; Brat, D.J.; Capper, D.; Cree, I.A.; Eberhart, C.; Figarella-Branger, D.; Fouladi, M.; Fuller, G.N.; et al. cIMPACT-NOW update 6: New entity and diagnostic principle recommendations of the cIMPACT-Utrecht meeting on future CNS tumor classification and grading. Brain Pathol. 2020, 30, 844-856. [CrossRef]

30. Ellison, D.W.; Aldape, K.D.; Capper, D.; Fouladi, M.; Gilbert, M.R.; Gilbertson, R.J.; Hawkins, C.; Merchant, T.E.; Pajtler, K.; Venneti, S.; et al. cIMPACT-NOW update 7: Advancing the molecular classification of ependymal tumors. Brain Pathol. 2020, 30, 863-866. [CrossRef]

31. Liang, B.C. Effects of hypoxia on drug resistance phenotype and genotype in human glioma cell lines. J. Neuro-Oncol. 1996, 29, 149-155. [CrossRef]

32. Semenza, G.L. Intratumoral hypoxia, radiation resistance, and HIF-1. Cancer Cell 2004, 5, 405-406. [CrossRef]

33. Vaupel, P.; Mayer, A. Hypoxia in cancer: Significance and impact on clinical outcome. Cancer Metastasis Rev. 2007, 26, 225-239. [CrossRef] [PubMed]

34. Gray, L.H.; Conger, A.D.; Ebert, M.; Hornsey, S.; Scott, O.C. The concentration of oxygen dissolved in tissues at the time of irradiation as a factor in radiotherapy. Br. J. Radiol. 1953, 26, 638-648. [CrossRef]

35. Heddleston, J.M.; Li, Z.; McLendon, R.E.; Hjelmeland, A.B.; Rich, J.N. The hypoxic microenvironment maintains glioblastoma stem cells and promotes reprogramming towards a cancer stem cell phenotype. Cell Cycle 2009, 8, 3274-3284. [CrossRef] [PubMed]

36. Kessler, J.; Hahnel, A.; Wichmann, H.; Rot, S.; Kappler, M.; Bache, M.; Vordermark, D. HIF-1 $\alpha$ inhibition by siRNA or chetomin in human malignant glioma cells: Effects on hypoxic radioresistance and monitoring via CA9 expression. BMC Cancer 2010, 10, 605. [CrossRef] [PubMed]

37. Bao, S.; Wu, Q.; McLendon, R.E.; Hao, Y.; Shi, Q.; Hjelmeland, A.B.; Dewhirst, M.W.; Bigner, D.D.; Rich, J.N. Glioma stem cells promote radioresistance by preferential activation of the DNA damage response. Nature 2006, 444, 756-760. [CrossRef]

38. Soeda, A.; Park, M.; Lee, D.; Mintz, A.; Androutsellis-Theotokis, A.; McKay, R.D.; Engh, J.; Iwama, T.; Kunisada, T.; Kassam, A.B.; et al. Hypoxia promotes expansion of the CD133-positive glioma stem cells through activation of HIF-1alpha. Oncogene 2009, 28, 3949-3959. [CrossRef] 
39. Colwell, N.; Larion, M.; Giles, A.J.; Seldomridge, A.N.; Sizdahkhani, S.; Gilbert, M.R.; Park, D.M. Hypoxia in the glioblastoma microenvironment: Shaping the phenotype of cancer stem-like cells. Neuro-Oncol. 2017, 19, 887-896. [CrossRef] [PubMed]

40. Biserova, K.; Jakovlevs, A.; Uljanovs, R.; Strumfa, I. Cancer Stem Cells: Significance in Origin, Pathogenesis and Treatment of Glioblastoma. Cells 2021, 10, 621. [CrossRef]

41. Lathia, J.D.; Mack, S.C.; Mulkearns-Hubert, E.E.; Valentim, C.L.; Rich, J.N. Cancer stem cells in glioblastoma. Genes Dev. 2015, 29, 1203-1217. [CrossRef]

42. Jackson, M.; Hassiotou, F.; Nowak, A. Glioblastoma stem-like cells: At the root of tumor recurrence and a therapeutic target. Carcinogenesis 2015, 36, 177-185. [CrossRef] [PubMed]

43. Mihaylova, V.T.; Bindra, R.S.; Yuan, J.; Campisi, D.; Narayanan, L.; Jensen, R.; Giordano, F.; Johnson, R.S.; Rockwell, S.; Glazer, P.M. Decreased expression of the DNA mismatch repair gene Mlh1 under hypoxic stress in mammalian cells. Mol. Cell. Biol. 2003, 23, 3265-3273. [CrossRef]

44. Li, Z.; Bao, S.; Wu, Q.; Wang, H.; Eyler, C.; Sathornsumetee, S.; Shi, Q.; Cao, Y.; Lathia, J.; McLendon, R.E.; et al. Hypoxia-inducible factors regulate tumorigenic capacity of glioma stem cells. Cancer Cell 2009, 15, 501-513. [CrossRef] [PubMed]

45. Semenza, G.L. Cancer-stromal cell interactions mediated by hypoxia-inducible factors promote angiogenesis, lymphangiogenesis, and metastasis. Oncogene 2013, 32, 4057-4063. [CrossRef] [PubMed]

46. Oka, N.; Soeda, A.; Inagaki, A.; Onodera, M.; Maruyama, H.; Hara, A.; Kunisada, T.; Mori, H.; Iwama, T. VEGF promotes tumorigenesis and angiogenesis of human glioblastoma stem cells. Biochem. Biophys. Res. Commun. 2007, 360, 553-559. [CrossRef]

47. Hamerlik, P.; Lathia, J.D.; Rasmussen, R.; Wu, Q.; Bartkova, J.; Lee, M.; Moudry, P.; Bartek, J., Jr.; Fischer, W.; Lukas, J.; et al. Autocrine VEGF-VEGFR2-Neuropilin-1 signaling promotes glioma stem-like cell viability and tumor growth. J. Exp. Med. 2012, 209, 507-520. [CrossRef] [PubMed]

48. Du, R.; Lu, K.V.; Petritsch, C.; Liu, P.; Ganss, R.; Passegué, E.; Song, H.; Vandenberg, S.; Johnson, R.S.; Werb, Z.; et al. HIF1alpha induces the recruitment of bone marrow-derived vascular modulatory cells to regulate tumor angiogenesis and invasion. Cancer Cell 2008, 13, 206-220. [CrossRef]

49. Folkins, C.; Shaked, Y.; Man, S.; Tang, T.; Lee, C.R.; Zhu, Z.; Hoffman, R.M.; Kerbel, R.S. Glioma tumor stem-like cells promote tumor angiogenesis and vasculogenesis via vascular endothelial growth factor and stromal-derived factor 1. Cancer Res. 2009, 69, 7243-7251. [CrossRef] [PubMed]

50. Joseph, J.V.; Conroy, S.; Pavlov, K.; Sontakke, P.; Tomar, T.; Eggens-Meijer, E.; Balasubramaniyan, V.; Wagemakers, M.; den Dunnen, W.F.; Kruyt, F.A. Hypoxia enhances migration and invasion in glioblastoma by promoting a mesenchymal shift mediated by the HIF1 $\alpha$-ZEB1 axis. Cancer Lett. 2015, 359, 107-116. [CrossRef]

51. Xu, H.; Rahimpour, S.; Nesvick, C.L.; Zhang, X.; Ma, J.; Zhang, M.; Zhang, G.; Wang, L.; Yang, C.; Hong, C.S.; et al. Activation of hypoxia signaling induces phenotypic transformation of glioma cells: Implications for bevacizumab antiangiogenic therapy. Oncotarget 2015, 6, 11882-11893. [CrossRef]

52. Tam, S.Y.; Wu, V.W.C.; Law, H.K.W. Hypoxia-Induced Epithelial-Mesenchymal Transition in Cancers: HIF-1 $\alpha$ and Beyond. Front. Oncol. 2020, 10, 486. [CrossRef] [PubMed]

53. Mudassar, F.; Shen, H.; O'Neill, G.; Hau, E. Targeting tumor hypoxia and mitochondrial metabolism with anti-parasitic drugs to improve radiation response in high-grade gliomas. J. Exp. Clin. Cancer Res. 2020, 39, 208. [CrossRef]

54. Stupp, R.; Mason, W.P.; van den Bent, M.J.; Weller, M.; Fisher, B.; Taphoorn, M.J.; Belanger, K.; Brandes, A.A.; Marosi, C.; Bogdahn, U.; et al. Radiotherapy plus concomitant and adjuvant temozolomide for glioblastoma. N. Engl. J. Med. 2005, 352, 987-996. [CrossRef] [PubMed]

55. Perry, J.R.; Laperriere, N.; O'Callaghan, C.J.; Brandes, A.A.; Menten, J.; Phillips, C.; Fay, M.; Nishikawa, R.; Cairncross, J.G.; Roa, W.; et al. Short-Course Radiation plus Temozolomide in Elderly Patients with Glioblastoma. N. Engl. J. Med. 2017, 376, $1027-1037$. [CrossRef]

56. Weller, M.; van den Bent, M.; Tonn, J.C.; Stupp, R.; Preusser, M.; Cohen-Jonathan-Moyal, E.; Henriksson, R.; Le Rhun, E.; Balana, C.; Chinot, O.; et al. European Association for Neuro-Oncology (EANO) guideline on the diagnosis and treatment of adult astrocytic and oligodendroglial gliomas. Lancet Oncol. 2017, 18, e315-e329. [CrossRef]

57. Shweiki, D.; Itin, A.; Soffer, D.; Keshet, E. Vascular endothelial growth factor induced by hypoxia may mediate hypoxia-initiated angiogenesis. Nature 1992, 359, 843-845. [CrossRef] [PubMed]

58. Weindel, K.; Moringlane, J.R.; Marmé, D.; Weich, H.A. Detection and quantification of vascular endothelial growth factor/vascular permeability factor in brain tumor tissue and cyst fluid: The key to angiogenesis? Neurosurgery 1994, 35, 439-448; discussion 448-449. [CrossRef]

59. Weathers, S.P.; de Groot, J. VEGF Manipulation in Glioblastoma. Oncology 2015, 29, 720-727. [PubMed]

60. Robles Irizarry, L.; Hambardzumyan, D.; Nakano, I.; Gladson, C.L.; Ahluwalia, M.S. Therapeutic targeting of VEGF in the treatment of glioblastoma. Expert Opin. Ther. Targets 2012, 16, 973-984. [CrossRef]

61. Cohen, M.H.; Shen, Y.L.; Keegan, P.; Pazdur, R. FDA drug approval summary: Bevacizumab (Avastin) as treatment of recurrent glioblastoma multiforme. Oncology 2009, 14, 1131-1138.

62. Conroy, S.; Wagemakers, M.; Walenkamp, A.M.; Kruyt, F.A.; den Dunnen, W.F. Novel insights into vascularization patterns and angiogenic factors in glioblastoma subclasses. J. Neuro-Oncol. 2017, 131, 11-20. [CrossRef] 
63. Sandmann, T.; Bourgon, R.; Garcia, J.; Li, C.; Cloughesy, T.; Chinot, O.L.; Wick, W.; Nishikawa, R.; Mason, W.; Henriksson, R.; et al. Patients with Proneural Glioblastoma May Derive Overall Survival Benefit From the Addition of Bevacizumab to First-Line Radiotherapy and Temozolomide: Retrospective Analysis of the AVAglio Trial. J. Clin. Oncol. Off. J. Am. Soc. Clin. Oncol. 2015, 33, 2735-2744. [CrossRef] [PubMed]

64. Bumes, E.; Rzonsa, S.; Hutterer, M.; Proescholdt, M.; Bogdahn, U.; Riemenschneider, M.J.; Uhl, M.; Wendl, C.; Hau, P. Adverse event grading following CTCAE v3.0 underestimates hypertensive side effects in patients with glioma treated with Bevacizumab. J. Neuro-Oncol. 2016, 127, 191-200. [CrossRef] [PubMed]

65. Garcia, J.; Hurwitz, H.I.; Sandler, A.B.; Miles, D.; Coleman, R.L.; Deurloo, R.; Chinot, O.L. Bevacizumab (Avastin®) in cancer treatment: A review of 15 years of clinical experience and future outlook. Cancer Treat. Rev. 2020, 86, 102017. [CrossRef] [PubMed]

66. Funakoshi, Y.; Hata, N.; Kuga, D.; Hatae, R.; Sangatsuda, Y.; Fujioka, Y.; Takigawa, K.; Mizoguchi, M. Update on Chemotherapeutic Approaches and Management of Bevacizumab Usage for Glioblastoma. Pharmaceuticals 2020, 13, 470. [CrossRef]

67. Piao, Y.; Liang, J.; Holmes, L.; Henry, V.; Sulman, E.; de Groot, J.F. Acquired resistance to anti-VEGF therapy in glioblastoma is associated with a mesenchymal transition. Clin. Cancer Res. Off. J. Am. Assoc. Cancer Res. 2013, 19, 4392-4403. [CrossRef]

68. Iwadate, Y. Epithelial-mesenchymal transition in glioblastoma progression. Oncol. Lett. 2016, 11, 1615-1620. [CrossRef]

69. Huang, W.; Zhang, C.; Cui, M.; Niu, J.; Ding, W. Inhibition of Bevacizumab-induced Epithelial-Mesenchymal Transition by BATF2 Overexpression Involves the Suppression of Wnt/ $\beta$-Catenin Signaling in Glioblastoma Cells. Anticancer Res. 2017, 37, 4285-4294.

70. Salazar, M.; Carracedo, A.; Salanueva, I.J.; Hernández-Tiedra, S.; Lorente, M.; Egia, A.; Vázquez, P.; Blázquez, C.; Torres, S.; García, S.; et al. Cannabinoid action induces autophagy-mediated cell death through stimulation of ER stress in human glioma cells. J. Clin. Investig. 2009, 119, 1359-1372. [CrossRef]

71. Wang, J.; Wang, H.; Sun, K.; Wang, X.; Pan, H.; Zhu, J.; Ji, X.; Li, X. Chrysin suppresses proliferation, migration, and invasion in glioblastoma cell lines via mediating the ERK/Nrf2 signaling pathway. Drug Des. Dev. Ther. 2018, 12, 721-733. [CrossRef]

72. van den Bent, M.J.; Brandes, A.A.; Rampling, R.; Kouwenhoven, M.C.; Kros, J.M.; Carpentier, A.F.; Clement, P.M.; Frenay, M.; Campone, M.; Baurain, J.F.; et al. Randomized phase II trial of erlotinib versus temozolomide or carmustine in recurrent glioblastoma: EORTC brain tumor group study 26034. J. Clin. Oncol. Off. J. Am. Soc. Clin. Oncol. 2009, 27, 1268-1274. [CrossRef]

73. Agarwal, S.; Manchanda, P.; Vogelbaum, M.A.; Ohlfest, J.R.; Elmquist, W.F. Function of the blood-brain barrier and restriction of drug delivery to invasive glioma cells: Findings in an orthotopic rat xenograft model of glioma. Drug Metab. Dispos. Biol. Fate Chem. 2013, 41, 33-39. [CrossRef]

74. Lombardi, G.; De Salvo, G.L.; Brandes, A.A.; Eoli, M.; Rudà, R.; Faedi, M.; Lolli, I.; Pace, A.; Daniele, B.; Pasqualetti, F.; et al. Regorafenib compared with lomustine in patients with relapsed glioblastoma (REGOMA): A multicentre, open-label, randomised, controlled, phase 2 trial. Lancet Oncol. 2019, 20, 110-119. [CrossRef]

75. Zeiner, P.S.; Kinzig, M.; Divé, I.; Maurer, G.D.; Filipski, K.; Harter, P.N.; Senft, C.; Bähr, O.; Hattingen, E.; Steinbach, J.P.; et al. Regorafenib CSF Penetration, Efficacy, and MRI Patterns in Recurrent Malignant Glioma Patients. J. Clin. Med. 2019, 8, 2031. [CrossRef] [PubMed]

76. Indraccolo, S.; De Salvo, G.L.; Verza, M.; Caccese, M.; Esposito, G.; Piga, I.; Del Bianco, P.; Pizzi, M.; Gardiman, M.P.; Eoli, M.; et al. Phosphorylated Acetyl-CoA Carboxylase Is Associated with Clinical Benefit with Regorafenib in Relapsed Glioblastoma: REGOMA Trial Biomarker Analysis. Clin. Cancer Res. Off. J. Am. Assoc. Cancer Res. 2020, 26, 4478-4484. [CrossRef]

77. Santangelo, A.; Rossato, M.; Lombardi, G.; Benfatto, S.; Lavezzari, D.; De Salvo, G.L.; Indraccolo, S.; Dechecchi, M.C.; Prandini, P.; Gambari, R.; et al. A molecular signature associated with prolonged survival in glioblastoma patients treated with regorafenib. Neuro-Oncol. 2021, 23, 264-276. [CrossRef] [PubMed]

78. Detti, B.; Scoccianti, S.; Lucidi, S.; Maragna, V.; Teriaca, M.A.; Ganovelli, M.; Desideri, I.; Lorenzetti, V.; Scoccimarro, E.; Greto, D.; et al. Regorafenib in glioblastoma recurrence: A case report. Cancer Treat. Res. Commun. 2021, 26, 100263. [CrossRef] [PubMed]

79. Harmar, A.J.; Arimura, A.; Gozes, I.; Journot, L.; Laburthe, M.; Pisegna, J.R.; Rawlings, S.R.; Robberecht, P.; Said, S.I.; Sreedharan, S.P.; et al. International Union of Pharmacology. XVIII. Nomenclature of receptors for vasoactive intestinal peptide and pituitary adenylate cyclase-activating polypeptide. Pharmacol. Rev. 1998, 50, 265-270.

80. Arimura, A.; Somogyvári-Vigh, A.; Miyata, A.; Mizuno, K.; Coy, D.H.; Kitada, C. Tissue distribution of PACAP as determined by RIA: Highly abundant in the rat brain and testes. Endocrinology 1991, 129, 2787-2789. [CrossRef]

81. Arimura, A.; Somogyvari-Vigh, A.; Weill, C.; Fiore, R.C.; Tatsuno, I.; Bay, V.; Brenneman, D.E. PACAP functions as a neurotrophic factor. Ann. N. Y. Acad. Sci. 1994, 739, 228-243. [CrossRef] [PubMed]

82. Arimura, A. Perspectives on pituitary adenylate cyclase activating polypeptide (PACAP) in the neuroendocrine, endocrine, and nervous systems. Jpn. J. Physiol. 1998, 48, 301-331. [CrossRef] [PubMed]

83. Rivnyak, A.; Kiss, P.; Tamas, A.; Balogh, D.; Reglodi, D. Review on PACAP-Induced Transcriptomic and Proteomic Changes in Neuronal Development and Repair. Int. J. Mol. Sci. 2018, 19, 1020. [CrossRef] [PubMed]

84. Boucher, M.N.; May, V.; Braas, K.M.; Hammack, S.E. PACAP orchestration of stress-related responses in neural circuits. Peptides 2021, 142, 170554. [CrossRef]

85. Miyata, A.; Jiang, L.; Dahl, R.D.; Kitada, C.; Kubo, K.; Fujino, M.; Minamino, N.; Arimura, A. Isolation of a neuropeptide corresponding to the $\mathrm{N}$-terminal 27 residues of the pituitary adenylate cyclase activating polypeptide with 38 residues (PACAP38). Biochem. Biophys. Res. Commun. 1990, 170, 643-648. [CrossRef] 
86. Segre, G.V.; Goldring, S.R. Receptors for secretin, calcitonin, parathyroid hormone (PTH)/PTH-related peptide, vasoactive intestinal peptide, glucagonlike peptide 1, growth hormone-releasing hormone, and glucagon belong to a newly discovered G-protein-linked receptor family. Trends Endocrinol. Metab. 1993, 4, 309-314. [CrossRef]

87. Vaudry, D.; Falluel-Morel, A.; Bourgault, S.; Basille, M.; Burel, D.; Wurtz, O.; Fournier, A.; Chow, B.K.; Hashimoto, H.; Galas, L.; et al. Pituitary adenylate cyclase-activating polypeptide and its receptors: 20 years after the discovery. Pharmacol. Rev. 2009, 61, 283-357. [CrossRef] [PubMed]

88. Harmar, A.J.; Fahrenkrug, J.; Gozes, I.; Laburthe, M.; May, V.; Pisegna, J.R.; Vaudry, D.; Vaudry, H.; Waschek, J.A.; Said, S.I. Pharmacology and functions of receptors for vasoactive intestinal peptide and pituitary adenylate cyclase-activating polypeptide: IUPHAR review 1. Br. J. Pharmacol. 2012, 166, 4-17. [CrossRef]

89. Blechman, J.; Levkowitz, G. Alternative Splicing of the Pituitary Adenylate Cyclase-Activating Polypeptide Receptor PAC1: Mechanisms of Fine Tuning of Brain Activity. Front. Endocrinol. 2013, 4, 55. [CrossRef]

90. Jolivel, V.; Basille, M.; Aubert, N.; de Jouffrey, S.; Ancian, P.; Le Bigot, J.F.; Noack, P.; Massonneau, M.; Fournier, A.; Vaudry, H.; et al. Distribution and functional characterization of pituitary adenylate cyclase-activating polypeptide receptors in the brain of non-human primates. Neuroscience 2009, 160, 434-451. [CrossRef]

91. Reglodi, D.; Kiss, P.; Horvath, G.; Lubics, A.; Laszlo, E.; Tamas, A.; Racz, B.; Szakaly, P. Effects of pituitary adenylate cyclase activating polypeptide in the urinary system, with special emphasis on its protective effects in the kidney. Neuropeptides 2012, 46, 61-70. [CrossRef]

92. Reglodi, D.; Illes, A.; Opper, B.; Schafer, E.; Tamas, A.; Horvath, G. Presence and Effects of Pituitary Adenylate Cyclase Activating Polypeptide Under Physiological and Pathological Conditions in the Stomach. Front. Endocrinol. 2018, 9, 90. [CrossRef]

93. Horvath, G.; Opper, B.; Reglodi, D. The Neuropeptide Pituitary Adenylate Cyclase-Activating Polypeptide (PACAP) is Protective in Inflammation and Oxidative Stress-Induced Damage in the Kidney. Int. J. Mol. Sci. 2019, 20, 4944. [CrossRef] [PubMed]

94. Szegeczki, V.; Bauer, B.; Jüngling, A.; Fülöp, B.D.; Vágó, J.; Perényi, H.; Tarantini, S.; Tamás, A.; Zákány, R.; Reglődi, D.; et al. Age-related alterations of articular cartilage in pituitary adenylate cyclase-activating polypeptide (PACAP) gene-deficient mice. GeroScience 2019, 41, 775-793. [CrossRef]

95. Vaudry, D.; Gonzalez, B.J.; Basille, M.; Yon, L.; Fournier, A.; Vaudry, H. Pituitary adenylate cyclase-activating polypeptide and its receptors: From structure to functions. Pharmacol. Rev. 2000, 52, 269-324. [PubMed]

96. Pisegna, J.R.; Wank, S.A. Cloning and characterization of the signal transduction of four splice variants of the human pituitary adenylate cyclase activating polypeptide receptor. Evidence for dual coupling to adenylate cyclase and phospholipase C. J. Biol. Chem. 1996, 271, 17267-17274. [CrossRef]

97. Pantaloni, C.; Brabet, P.; Bilanges, B.; Dumuis, A.; Houssami, S.; Spengler, D.; Bockaert, J.; Journot, L. Alternative splicing in the N-terminal extracellular domain of the pituitary adenylate cyclase-activating polypeptide (PACAP) receptor modulates receptor selectivity and relative potencies of PACAP-27 and PACAP-38 in phospholipase C activation. J. Biol. Chem. 1996, 271, 22146-22151. [CrossRef] [PubMed]

98. Ushiyama, M.; Ikeda, R.; Sugawara, H.; Yoshida, M.; Mori, K.; Kangawa, K.; Inoue, K.; Yamada, K.; Miyata, A. Differential intracellular signaling through PAC1 isoforms as a result of alternative splicing in the first extracellular domain and the third intracellular loop. Mol. Pharmacol. 2007, 72, 103-111. [CrossRef]

99. Pisegna, J.R.; Moody, T.W.; Wank, S.A. Differential signaling and immediate-early gene activation by four splice variants of the human pituitary adenylate cyclase-activating polypeptide receptor (hPACAP-R). Ann. N. Y. Acad. Sci. 1996, 805, 54-64; discussion 64-66. [CrossRef]

100. Spengler, D.; Waeber, C.; Pantaloni, C.; Holsboer, F.; Bockaert, J.; Seeburg, P.H.; Journot, L. Differential signal transduction by five splice variants of the PACAP receptor. Nature 1993, 365, 170-175.

101. Braas, K.M.; May, V. Pituitary adenylate cyclase-activating polypeptides directly stimulate sympathetic neuron neuropeptide $\mathrm{Y}$ release through PAC(1) receptor isoform activation of specific intracellular signaling pathways. J. Biol. Chem. 1999, 274, 27702-27710. [CrossRef]

102. Sokołowska, P.; Dejda, A.; Nowak, J.Z. Neuroprotective role of PACAP, VIP, and PHI in the central nervous system. Postepy Hig. Med. Dosw. (Online) 2004, 58, 416-427. [PubMed]

103. Reglodi, D.; Lubics, A.; Tamás, A.; Szalontay, L.; Lengvári, I. Pituitary adenylate cyclase activating polypeptide protects dopaminergic neurons and improves behavioral deficits in a rat model of Parkinson's disease. Behav. Brain Res. 2004, 151, 303-312. [CrossRef] [PubMed]

104. Reglodi, D.; Jungling, A.; Longuespée, R.; Kriegsmann, J.; Casadonte, R.; Kriegsmann, M.; Juhasz, T.; Bardosi, S.; Tamas, A.; Fulop, B.D.; et al. Accelerated pre-senile systemic amyloidosis in PACAP knockout mice-A protective role of PACAP in age-related degenerative processes. J. Pathol. 2018, 245, 478-490. [CrossRef] [PubMed]

105. Bonaventura, G.; Iemmolo, R.; D’Amico, A.G.; La Cognata, V.; Costanzo, E.; Zappia, M.; D’Agata, V.; Conforti, F.L.; Aronica, E.; Cavallaro, S. PACAP and PAC1R are differentially expressed in motor cortex of amyotrophic lateral sclerosis patients and support survival of iPSC-derived motor neurons. J. Cell. Physiol. 2018, 233, 3343-3351. [CrossRef] [PubMed]

106. Maugeri, G.; D’Amico, A.G.; Morello, G.; Reglodi, D.; Cavallaro, S.; D’Agata, V. Differential Vulnerability of Oculomotor Versus Hypoglossal Nucleus During ALS: Involvement of PACAP. Front. Neurosci. 2020, 14, 805. [CrossRef]

107. Maugeri, G.; D'Amico, A.G.; Musumeci, G.; Reglodi, D.; D'Agata, V. Effects of Pacap on Schwann Cells: Focus on Nerve Injury. Int. J. Mol. Sci. 2020, 21, 8233. [CrossRef] 
108. Solés-Tarrés, I.; Cabezas-Llobet, N.; Vaudry, D.; Xifró, X. Protective Effects of Pituitary Adenylate Cyclase-Activating Polypeptide and Vasoactive Intestinal Peptide Against Cognitive Decline in Neurodegenerative Diseases. Front. Cell. Neurosci. 2020, $14,221$. [CrossRef]

109. D'Amico, A.G.; Maugeri, G.; Musumeci, G.; Reglodi, D.; D'Agata, V. PACAP and NAP: Effect of Two Functionally Related Peptides in Diabetic Retinopathy. J. Mol. Neurosci. 2021. [CrossRef]

110. D'Amico, A.G.; Maugeri, G.; Saccone, S.; Federico, C.; Cavallaro, S.; Reglodi, D.; D'Agata, V. PACAP Modulates the Autophagy Process in an In Vitro Model of Amyotrophic Lateral Sclerosis. Int. J. Mol. Sci. 2020, 21, 2943. [CrossRef]

111. Yu, R.; Li, J.; Lin, Z.; Ouyang, Z.; Huang, X.; Reglodi, D.; Vaudry, D. TAT-tagging of VIP exerts positive allosteric modulation of the PAC1 receptor and enhances VIP neuroprotective effect in the MPTP mouse model of Parkinson's disease. Biochim. Biophys. Acta. Gen. Subj. 2020, 1864, 129626. [CrossRef]

112. Jungling, A.; Reglodi, D.; Maasz, G.; Zrinyi, Z.; Schmidt, J.; Rivnyak, A.; Horvath, G.; Pirger, Z.; Tamas, A. Alterations of Nigral Dopamine Levels in Parkinson's Disease after Environmental Enrichment and PACAP Treatment in Aging Rats. Life 2021, 11, 35. [CrossRef] [PubMed]

113. Moody, T.W.; Jensen, R.T. Pituitary adenylate cyclase-activating polypeptide/vasoactive intestinal peptide [Part 1]: Biology, pharmacology, and new insights into their cellular basis of action/signaling which are providing new therapeutic targets. Curr. Opin. Endocrinol. Diabetes Obes. 2021, 28, 198-205. [CrossRef]

114. Moody, T.W.; Jensen, R.T. Pituitary adenylate cyclase-activating polypeptide/vasoactive intestinal peptide (Part 2): Biology and clinical importance in central nervous system and inflammatory disorders. Curr. Opin. Endocrinol. Diabetes Obes. 2021, 28, 206-213. [CrossRef] [PubMed]

115. Maugeri, G.; D’Amico, A.G.; Rasà, D.M.; Federico, C.; Saccone, S.; Morello, G.; La Cognata, V.; Cavallaro, S.; D'Agata, V. Molecular mechanisms involved in the protective effect of pituitary adenylate cyclase-activating polypeptide in an in vitro model of amyotrophic lateral sclerosis. J. Cell. Physiol. 2019, 234, 5203-5214. [CrossRef] [PubMed]

116. Waschek, J.A.; Dicicco-Bloom, E.M.; Lelievre, V.; Zhou, X.; Hu, Z. PACAP action in nervous system development, regeneration, and neuroblastoma cell proliferation. Ann. N. Y. Acad. Sci. 2000, 921, 129-136. [CrossRef]

117. Nakamura, K.; Nakamachi, T.; Endo, K.; Ito, K.; Machida, T.; Oka, T.; Hori, M.; Ishizaka, K.; Shioda, S. Distribution of pituitary adenylate cyclase-activating polypeptide (PACAP) in the human testis and in testicular germ cell tumors. Andrologia 2014, 46, 465-471. [CrossRef]

118. Ferencz, S.; Reglodi, D.; Kaszas, B.; Bardosi, A.; Toth, D.; Vekony, Z.; Vicena, V.; Karadi, O.; Kelemen, D. PACAP and PAC1 receptor expression in pancreatic ductal carcinoma. Oncol. Lett. 2019, 18, 5725-5730. [CrossRef]

119. Farini, D.; Puglianiello, A.; Mammi, C.; Siracusa, G.; Moretti, C. Dual effect of pituitary adenylate cyclase activating polypeptide on prostate tumor LNCaP cells: Short- and long-term exposure affect proliferation and neuroendocrine differentiation. Endocrinology 2003, 144, 1631-1643. [CrossRef]

120. Lelièvre, V.; Pineau, N.; Du, J.; Wen, C.H.; Nguyen, T.; Janet, T.; Muller, J.M.; Waschek, J.A. Differential effects of peptide histidine isoleucine (PHI) and related peptides on stimulation and suppression of neuroblastoma cell proliferation. A novel VIP-independent action of PHI via MAP kinase. J. Biol. Chem. 1998, 273, 19685-19690. [CrossRef]

121. Moody, T.W.; Chan, D.; Fahrenkrug, J.; Jensen, R.T. Neuropeptides as autocrine growth factors in cancer cells. Curr. Pharm. Des. 2003, 9, 495-509. [CrossRef]

122. García-Fernández, M.O.; Bodega, G.; Ruíz-Villaespesa, A.; Cortés, J.; Prieto, J.C.; Carmena, M.J. PACAP expression and distribution in human breast cancer and healthy tissue. Cancer Lett. 2004, 205, 189-195. [CrossRef]

123. García-Fernández, M.O.; Bodega, G.; Solano, R.M.; Ruíz-Villaespesa, A.; Sánchez-Chapado, M.; Carmena, M.J.; Prieto, J.C. Expression and distribution of pituitary adenylate cyclase-activating peptide in human prostate and prostate cancer tissues. Regul. Pept. 2002, 110, 9-15. [CrossRef]

124. García-Fernández, M.O.; Collado, B.; Bodega, G.; Cortés, J.; Ruíz-Villaespesa, A.; Carmena, M.J.; Prieto, J.C. Pituitary adenylate cyclase-activating peptide/vasoactive intestinal peptide receptors in human normal mammary gland and breast cancer tissue. Gynecol. Endocrinol. Off. J. Int. Soc. Gynecol. Endocrinol. 2005, 20, 327-333. [CrossRef]

125. Szanto, Z.; Sarszegi, Z.; Reglodi, D.; Nemeth, J.; Szabadfi, K.; Kiss, P.; Varga, A.; Banki, E.; Csanaky, K.; Gaszner, B.; et al. PACAP immunoreactivity in human malignant tumor samples and cardiac diseases. J. Mol. Neurosci. 2012, 48, 667-673. [CrossRef] [PubMed]

126. Tamas, A.; Javorhazy, A.; Reglodi, D.; Sarlos, D.P.; Banyai, D.; Semjen, D.; Nemeth, J.; Lelesz, B.; Fulop, D.B.; Szanto, Z. Examination of PACAP-Like Immunoreactivity in Urogenital Tumor Samples. J. Mol. Neurosci. 2016, 59, 177-183. [CrossRef]

127. Bardosi, S.; Bardosi, A.; Nagy, Z.; Reglodi, D. Expression of PACAP and PAC1 Receptor in Normal Human Thyroid Gland and in Thyroid Papillary Carcinoma. J. Mol. Neurosci. 2016, 60, 171-178. [CrossRef]

128. Vertongen, P.; d'Haens, J.; Michotte, A.; Velkeniers, B.; van Rampelbergh, J.; Svoboda, M.; Robberecht, P. Expression of pituitary adenylate cyclase activating polypeptide and receptors in human brain tumors. Peptides 1995, 16, 713-719. [CrossRef]

129. Jaworski, D.M. Expression of pituitary adenylate cyclase-activating polypeptide (PACAP) and the PACAP-selective receptor in cultured rat astrocytes, human brain tumors, and in response to acute intracranial injury. Cell Tissue Res. 2000, 300, 219-230. [CrossRef] [PubMed]

130. Robberecht, P.; Woussen-Colle, M.C.; Vertongen, P.; De Neef, P.; Hou, X.; Salmon, I.; Brotchi, J. Expression of pituitary adenylate cyclase activating polypeptide (PACAP) receptors in human glial cell tumors. Peptides 1994, 15, 661-665. [CrossRef] 
131. Reubi, J.C.; Läderach, U.; Waser, B.; Gebbers, J.O.; Robberecht, P.; Laissue, J.A. Vasoactive intestinal peptide/pituitary adenylate cyclase-activating peptide receptor subtypes in human tumors and their tissues of origin. Cancer Res. 2000, 60, 3105-3112.

132. Sharma, A.; Walters, J.; Gozes, Y.; Fridkin, M.; Brenneman, D.; Gozes, I.; Moody, T.W. A vasoactive intestinal peptide antagonist inhibits the growth of glioblastoma cells. J. Mol. Neurosci. 2001, 17, 331-339. [CrossRef]

133. Barbarin, A.; Séité, P.; Godet, J.; Bensalma, S.; Muller, J.M.; Chadéneau, C. Atypical nuclear localization of VIP receptors in glioma cell lines and patients. Biochem. Biophys. Res. Commun. 2014, 454, 524-530. [CrossRef]

134. Vertongen, P.; Camby, I.; Darro, F.; Kiss, R.; Robberecht, P. VIP and pituitary adenylate cyclase activating polypeptide (PACAP) have an antiproliferative effect on the T98G human glioblastoma cell line through interaction with VIP2 receptor. Neuropeptides 1996, 30, 491-496. [CrossRef]

135. Sokolowska, P.; Nowak, J.Z. Effects of PACAP and VIP on cAMP-generating system and proliferation of C6 glioma cells. J. Mol. Neurosci. 2008, 36, 286-291. [CrossRef]

136. Dufes, C.; Alleaume, C.; Montoni, A.; Olivier, J.C.; Muller, J.M. Effects of the vasoactive intestinal peptide (VIP) and related peptides on glioblastoma cell growth in vitro. J. Mol. Neurosci. 2003, 21, 91-102. [CrossRef]

137. Cochaud, S.; Chevrier, L.; Meunier, A.C.; Brillet, T.; Chadéneau, C.; Muller, J.M. The vasoactive intestinal peptide-receptor system is involved in human glioblastoma cell migration. Neuropeptides 2010, 44, 373-383. [CrossRef] [PubMed]

138. Cochaud, S.; Meunier, A.C.; Monvoisin, A.; Bensalma, S.; Muller, J.M.; Chadéneau, C. Neuropeptides of the VIP family inhibit glioblastoma cell invasion. J. Neuro-Oncol. 2015, 122, 63-73. [CrossRef]

139. Bensalma, S.; Turpault, S.; Balandre, A.C.; De Boisvilliers, M.; Gaillard, A.; Chadéneau, C.; Muller, J.M. PKA at a Cross-Road of Signaling Pathways Involved in the Regulation of Glioblastoma Migration and Invasion by the Neuropeptides VIP and PACAP. Cancers 2019, 11, 123. [CrossRef] [PubMed]

140. Paw, I.; Carpenter, R.C.; Watabe, K.; Debinski, W.; Lo, H.W. Mechanisms regulating glioma invasion. Cancer Lett. $2015,362,1-7$. [CrossRef]

141. Kubiatowski, T.; Jang, T.; Lachyankar, M.B.; Salmonsen, R.; Nabi, R.R.; Quesenberry, P.J.; Litofsky, N.S.; Ross, A.H.; Recht, L.D. Association of increased phosphatidylinositol 3-kinase signaling with increased invasiveness and gelatinase activity in malignant gliomas. J. Neurosurg. 2001, 95, 480-488. [CrossRef]

142. Longo, V.D.; Fontana, L. Calorie restriction and cancer prevention: Metabolic and molecular mechanisms. Trends Pharmacol. Sci. 2010, 31, 89-98. [CrossRef] [PubMed]

143. Monteiro, A.R.; Hill, R.; Pilkington, G.J.; Madureira, P.A. The Role of Hypoxia in Glioblastoma Invasion. Cells 2017, 6, 45. [CrossRef]

144. Franovic, A.; Gunaratnam, L.; Smith, K.; Robert, I.; Patten, D.; Lee, S. Translational up-regulation of the EGFR by tumor hypoxia provides a nonmutational explanation for its overexpression in human cancer. Proc. Natl. Acad. Sci. USA 2007, 104, 13092-13097. [CrossRef] [PubMed]

145. Franovic, A.; Holterman, C.E.; Payette, J.; Lee, S. Human cancers converge at the HIF-2alpha oncogenic axis. Proc. Natl. Acad. Sci. USA 2009, 106, 21306-21311. [CrossRef] [PubMed]

146. Moody, T.W.; Osefo, N.; Nuche-Berenguer, B.; Ridnour, L.; Wink, D.; Jensen, R.T. Pituitary adenylate cyclase-activating polypeptide causes tyrosine phosphorylation of the epidermal growth factor receptor in lung cancer cells. J. Pharmacol. Exp. Ther. 2012, 341, 873-881. [CrossRef] [PubMed]

147. Moody, T.W.; Lee, L.; Iordanskaia, T.; Ramos-Alvarez, I.; Moreno, P.; Boudreau, H.E.; Leto, T.L.; Jensen, R.T. PAC1 regulates receptor tyrosine kinase transactivation in a reactive oxygen species-dependent manner. Peptides 2019, 120, 170017. [CrossRef]

148. Moody, T.W.; Lee, L.; Jensen, R.T. The G Protein-Coupled Receptor PAC1 Regulates Transactivation of the Receptor Tyrosine Kinase HER3. J. Mol. Neurosci. 2020. [CrossRef]

149. Grazia, M.; D’Amico, A.G.; Salvatore, S.; Concetta, F.; Maria, R.D.; Rosario, C.; Giuseppe, B.; Salvatore, G.; Giuseppe, M.; Velia, D. Effect of PACAP on hypoxia-induced angiogenesis and epithelial-mesenchymal transition in glioblastoma. Biomedicines. (under review).

150. Roomi, M.W.; Kalinovsky, T.; Rath, M.; Niedzwiecki, A. Modulation of MMP-2 and MMP-9 secretion by cytokines, inducers and inhibitors in human glioblastoma T-98G cells. Oncol. Rep. 2017, 37, 1907-1913. [CrossRef]

151. Nishikawa, M.; Inoue, A.; Ohnishi, T.; Kohno, S.; Ohue, S.; Matsumoto, S.; Suehiro, S.; Yamashita, D.; Ozaki, S.; Watanabe, H.; et al. Significance of Glioma Stem-Like Cells in the Tumor Periphery That Express High Levels of CD44 in Tumor Invasion, Early Progression, and Poor Prognosis in Glioblastoma. Stem Cells Int. 2018, 2018, 5387041. [CrossRef] [PubMed]

152. Nishikawa, M.; Inoue, A.; Ohnishi, T.; Yano, H.; Kanemura, Y.; Kohno, S.; Ohue, S.; Ozaki, S.; Matsumoto, S.; Suehiro, S.; et al. CD44 expression in the tumor periphery predicts the responsiveness to bevacizumab in the treatment of recurrent glioblastoma. Cancer Med. 2021, 10, 2013-2025. [CrossRef] [PubMed]

153. Nishikawa, M.; Inoue, A.; Ohnishi, T.; Yano, H.; Ozaki, S.; Kanemura, Y.; Suehiro, S.; Ohtsuka, Y.; Kohno, S.; Ohue, S.; et al. Hypoxia-induced phenotypic transition from highly invasive to less invasive tumors in glioma stem-like cells: Significance of CD44 and osteopontin as therapeutic targets in glioblastoma. Transl. Oncol. 2021, 14, 101137. [CrossRef] [PubMed] 